\title{
Comparison of the phlebotomine (Diptera: Psychodidae) fauna of urban, transitional, and wild areas in northern Minas Gerais, Brazil
}

Cristiani de Castilho Sanguinette ${ }^{1}$, Danyele Franca da Silva', Rodolfo German Antonelli Vidal Stumpp², Felipe Dutra Rego', Gabriel Barbosa Tonelli', Aline Tanure', Célia Maria Ferreira Gontijo ${ }^{1}$ and José Dilermando Andrade Filho ${ }^{1 *}$

\begin{abstract}
Background: Phlebotomines are directly related to the study of leishmaniases, and so the study of their distribution plays an important role in the epidemiology of these diseases. Collections of phlebotomines were made with the intent of comparing the distribution, richness, diversity, and abundance of species in three distinct environments in an area endemic for tegumentary and visceral leishmaniasis in Minas Gerais State, Brazil.

Methods: Phlebotomines were collected with automatic light traps in urban, transitional, and wild areas from March 2013 to February 2014 in the district of Barra do Guaicuí, municipality of Várzea da Palma, Minas Gerais. The distribution patterns of these species of insects, as well as species richness, evenness, and abundance among the different areas, were analyzed.
\end{abstract}

Results: A total of 3,365 phlebotomines belonging to 15 species were collected. The urban area had the greatest abundance whereas the transitional area had the greatest diversity and evenness of species. Nyssomyia intermedia was the most abundant species in the urban area, whereas Evandromyia evandroi was the most abundant in the transitional area and Ev. lenti in the wild area.

Conclusion: The analysis of our results showed that the distribution of the collected species had distinct profiles between the environments studied. Furthermore our study indicates the potential risk of transmission of leishmaniasis in the urban environment where it was observed had the highest population density and abundance of important vector species of Leishmania.

Keywords: Phlebotominae, Fauna, Vector ecology, Leishmaniasis

\section{Background}

Environmental changes derived from human actions, such as the rapid process of urbanization observed in emerging countries like Brazil, have changed the ecology of some species of phlebotomines and, consequently, the eco-epidemiology of the leishmaniases. In respect of visceral leishmaniasis these changes lead to a

\footnotetext{
* Correspondence: jandrade@cpqrr.fiocruz.br

'Leishmaniases Research Group, Phlebotomine Collection, National and International Reference Center for Phlebotomines, René Rachou Institute, Fiocruz, Av. Augusto de Lima 1715, 30190-002 Belo Horizonte, MG, Brasil Full list of author information is available at the end of the article
}

significant impact on the distribution and mortality rates of the disease since the 1980s $[1,2]$. Thus, four new patterns have emerged: the transmission of visceral leishmaniasis (VL) in fully urbanized areas; the rapid spread in cities of the Northeast and in various cities in the North, Central-West, and Southeast; an increase in the number of cases in urban areas compared to rural areas; and the emergence of large-scale urban epidemics with cycles of ten years [3].

The increase in the number of cases of tegumentary leishmaniasis (TL) and VL in Minas Gerais in recent years is documented by the System of Information of 
Disease Notification from 2000 to 2009, who reports that in Minas Gerais there is an average of 390 cases of VL annually [4, 5]. Currently, in Minas Gerais, the cities of Belo Horizonte, Montes Claros, Ribeirão da Neves, Janaúba, Santa Luzia and Paracatu correspond to $56 \%$ of the VL cases reported in the state [6].

The first case of TL in the municipality of Várzea da Palma was reported in 2001 in the district of Barra do Guaicui. Since then, from 2004 to 2013, 202 human cases of autochthonous TL and 37 cases of VL have been reported (Source: Municipal Secretary of Health of Várzea da Palma, MG).

One of the challenges related to the control of leishmaniases is the lack of knowledge about epidemiological conditions, especially regarding the distribution of phlebotomine populations, the behavior and the identification of these species. Thus, this study aims to present the distribution, richness, diversity, and abundance of species of phlebotomines related to urban, transitional, and wild environments in the district of Barra do Guaicuí, an endemic area for TL and VL in Minas Gerais state. Not only can this information provide a more accurate description of the current situation of the sand fly fauna, but it can also be predictive, and thus allowing the establishment of more effective control methods and epidemiological surveillance in the region.

\section{Methods}

\section{Study area}

The study area, Barra do Guaicui $\left(17^{\circ} 12^{\prime} \mathrm{S}\right.$ and $\left.44^{\circ} 48^{\prime} \mathrm{W}\right)$, is a district located in the municipality of Várzea da Palmain the northern region of Minas Gerais, Brazil (Fig 1). According to the Brazilian Institute of Geography and Statistics the municipality is represented by an area of $2,220.279 \mathrm{~km}^{2}$ and a population, estimated in 2014, of 38,213 inhabitants [7].

The municipality varies in elevation between 480 and $800 \mathrm{~m}$, with a mountain range that connects with the Serra do Cabral [8]. According to Köppen et al., the climate is classified as tropical savanna with a dry season in the winter [9]. Várzea da Palma is situated in the savannah (cerrado biome) although some open areas east of Várzea da Palma show a caatinga biome influence. Small fragments of forest in various states of succession are also present forming a mosaic of vegetation that varies in complexity from shrubs to very dense forest [10]. The prevalent phytophysiognomies are open fields, cerrado sensu stricto and seasonal deciduous montane forest, with the best preserved areas of vegetation being found at higher elevations [8].

\section{Collection of phlebotomine sand flies}

The urban area (A) is located in the center of the district of Barra do Guaicuí and has a population of 3,000 inhabitants, many brickwork buildings and some unoccupied areas that have become overgrown. The native vegetation, cerrado sensu stricto, is practically nonexistent and is replaced by other types of plants, principally mangos. The cerrado sensu stricto is characterized by the presence of low, twisted trees with irregular branches. The bushes and subshrubs are spread, with some species with perennial underground organs which allow regrowth after cutting or burning. The trunks of woody plants in general have shells with thick cork and rigid leathery leaves. These characters suggest adaptation to drought conditions. The organic matter content varies from medium to low [11].

The traps were exposed in the peridomiciliary areas and, when present, in chicken house, pig pen or kennel. These areas experiences flooding during the rainy season due to the close proximity of the Velhas River.

The transitional area (T1), or hemi-synanthropic area, is located in a remote village with a few nearby buildings. The sampled houses were at a distance of 10 meters from the forest and with the presence of animals such as horse, goat, chicken and dog, being created free. The native vegetation, seasonal deciduous montane forest, is present despite being widely used by residents as a source of firewood. Some nearby areas are used as pasture.

The wild area was sampled at three points (T2, T3 and T4) that were away from human habitations and feature native vegetation of seasonal deciduous preserved montane forest. This kind of forest has as a main feature two well-marked seasons, one rainy and the other a long drought in which more than half of the vegetation loses its leaves, allowing the presence of organic matter in the soil.

Phlebotomines were collected from March 2013 to February 2014 using HP-model automatic light traps [12]. A total of ten light traps were installed monthly: two in the transitional area (forest edge at a distance of 100 meters from the house); six in the wild area with two at each of the three sample points; and two in the peridomicile area of houses in the urban area (Fig 2). The traps were set during three consecutive nights from 18:00 to 6:00 hours, totaling 36 hours of sampling effort per night for each trap. In all study sites traps were installed about 1 meter from the ground.

The traps were removed after each night so that sorting and sexing of phlebotomines could be performed. All specimens were prepared, mounted, and identified according to the routine procedures adopted by the National and International Reference Center for Phlebotomines (CRNIF) of the René Rachou/FIOCRUZ Research Center [13].

The collected phlebotomines were identified to species level using light microscopy. The classification followed the proposal of Galati [14]. The abbreviation of the 


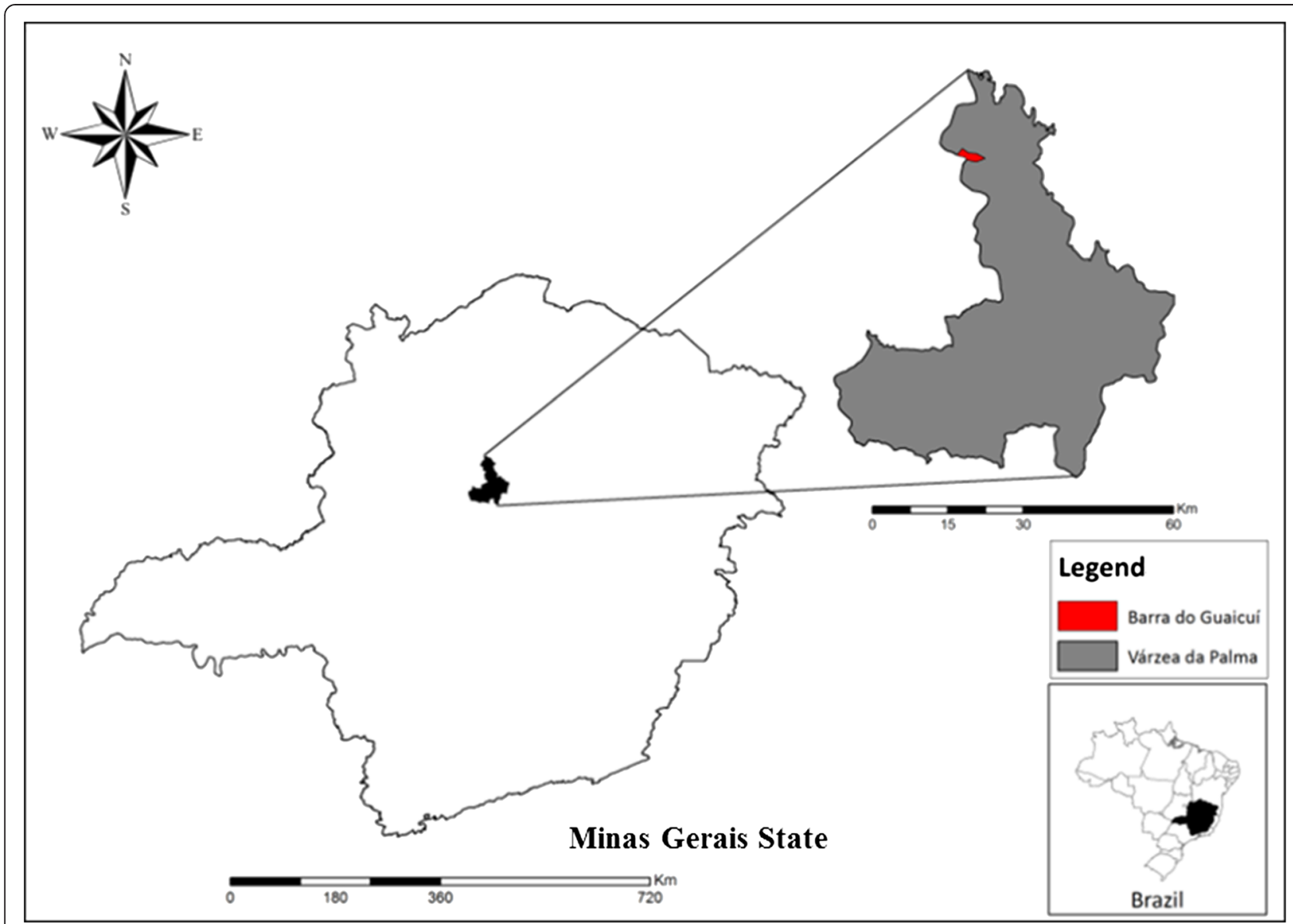

Fig. 1 Municipality of Várzea da Palma, showing the district of Barra do Guaicuí, in northern Minas Gerais, Brazil

generic names in this study follows the proposal of Marcondes [15].

The different number of traps in each area resulted in different sampling efforts. These differences were mitigated by multiplying the total number of traps in an area by the number of days the traps were working. The sampling effort was used to calculate capture success, which indicates the actual efficiency of a type of trap in an area. Capture success was calculated using the total number of individuals divided by the sampling effort.

For the evaluation of the most abundant species in each area, the Index of Species Abundance (ISA) was converted into a scale of zero to one by the Standardized Index of Species Abundance (SISA). In this index, value one corresponds to the most abundant species [16]. Richness is considered as the total number of species, and abundance is considered the total number of individuals collected. The diversity and evenness of species of phlebotomines from the different areas were estimated by using the diversity index of Shannon-Wiener $\left(\mathrm{H}^{\prime}\right)$ and Pielou $(\mathrm{J})$, respectively [17]. For the species most prevalent in the study, abundances were compared for each species between areas using Analysis of Variance (ANOVA).

\section{Ethical approval}

Collection procedures were approved by the "Ministério do Meio Ambiente do Brasil" - (SISBIO: license number 15,237).

\section{Results}

The phlebotomine fauna was represented by 15 species. Table 1 shows the total number of phlebotomines collected by study area, and also the Shannon diversity index $(\mathrm{H})$ and the evenness of Pielou $(\mathrm{J})$. The monthly samples yielded 3,365 specimens of phlebotomines, of which 1,900 were males $(56.46 \%)$ and 1,465 were females (43.54\%).

The urban area had the greatest number of phlebotomines collected with 2,012 individuals, followed by the forest area with 1,127 , and the transitional area with 226 . By standardizing the number of phlebotomines collected in the different areas, due to differences in sampling effort, the capture success was also highest in the urban area (27.94 phlebotomine/trap), followed by the forest area (5.22), and lastly the transitional area (3.14).

Considering all of the sampled areas, the species most frequently trapped was $N y$. intermedia with $34.92 \%$ of 


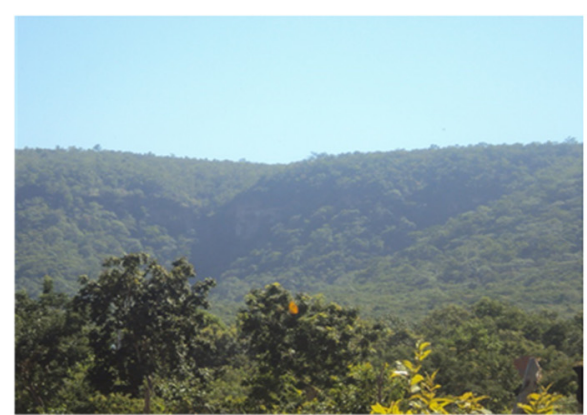

Wild area

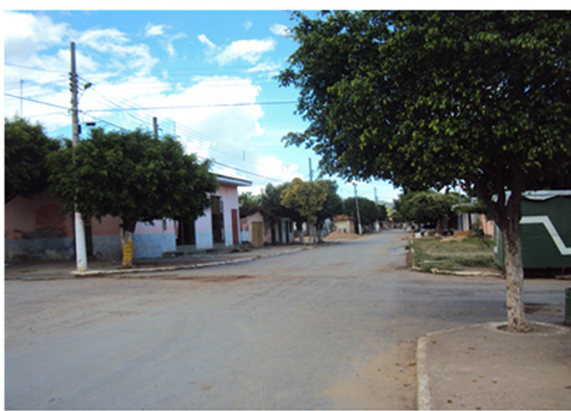

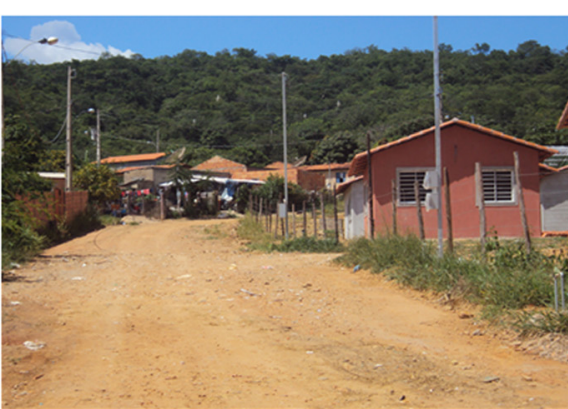

Transitional area

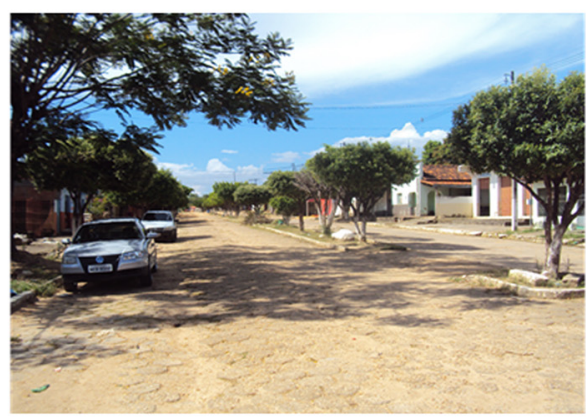

Urban area

Fig. 2 Localities where phlebotomines were collected in 2013 and 2014 in the district of Barra do Guaicui, Minas Gerais, Brazil

Table 1 Species of phlebotomines collected during March 2013 to February 2014 in the municipality of Várzea da Palma, Minas Gerais, Brasil, by study area and sex and with their respective diversity $(\mathrm{H})$ and evenness $(J)$ indicies

\begin{tabular}{|c|c|c|c|c|c|c|c|c|c|c|c|}
\hline \multirow{3}{*}{ Taxonomic category } & \multirow{2}{*}{\multicolumn{2}{|c|}{$\begin{array}{l}\text { Urban area } \\
\text { A }\end{array}$}} & \multirow{2}{*}{\multicolumn{2}{|c|}{$\begin{array}{l}\text { Transitional area } \\
\text { T1 }\end{array}$}} & \multicolumn{6}{|c|}{ Wild area } & \multirow[t]{3}{*}{ Total (\%) } \\
\hline & & & & & \multicolumn{2}{|l|}{$\mathrm{T} 2$} & \multicolumn{2}{|l|}{ T3 } & \multicolumn{2}{|l|}{$\mathrm{T} 4$} & \\
\hline & $\bar{F}$ & $M$ & $\bar{F}$ & $\bar{M}$ & $\bar{F}$ & $M$ & $\bar{F}$ & $\bar{M}$ & $\bar{F}$ & $M$ & \\
\hline Brumptomyia avellari & 13 & 15 & 33 & 25 & 48 & 102 & 9 & 10 & 22 & 40 & $317(9.42)$ \\
\hline Evandromyia evandroi & 6 & 8 & 49 & 9 & 141 & 19 & 29 & 4 & 97 & 16 & $378(11.23)$ \\
\hline Evandromyia lenti & 16 & 35 & 6 & 36 & 27 & 195 & 9 & 35 & 28 & 140 & $527(15.66)$ \\
\hline Evandromyia sallesi & 52 & 27 & 5 & 0 & 15 & 1 & 12 & 12 & 14 & 5 & $143(4.25)$ \\
\hline Evandromyia termitophila & 1 & 3 & 2 & 0 & 12 & 3 & 4 & 0 & 14 & 1 & $40(1.19)$ \\
\hline Evandromyia walkeri & 2 & 8 & 0 & 2 & 2 & 2 & 1 & 0 & 1 & 1 & $19(0.56)$ \\
\hline Lutzomyia longipalpis & 101 & 435 & 2 & 19 & 1 & 12 & 0 & 4 & 2 & 5 & $581(17.27)$ \\
\hline Micropygomyia quinquefer & 14 & 16 & 0 & 0 & 0 & 0 & 0 & 0 & 0 & 1 & $31(0.92)$ \\
\hline Nyssomyia intermedia & 589 & 539 & 10 & 17 & 1 & 4 & 4 & 2 & 9 & 0 & $1.175(34.92$ \\
\hline Nyssomyia neivai & 52 & 76 & 2 & 3 & 0 & 2 & 0 & 1 & 0 & 1 & $137(4.07)$ \\
\hline Nyssomyia whitmani & 0 & 0 & 1 & 0 & 0 & 0 & 0 & 0 & 0 & 0 & $1(0.03)$ \\
\hline Pintomya pessoai & 0 & 0 & 1 & 0 & 1 & 0 & 0 & 0 & 0 & 0 & $2(0.06)$ \\
\hline Psathyromyia lutziana & 0 & 1 & 2 & 0 & 0 & 1 & 0 & 0 & 0 & 0 & $4(0.12)$ \\
\hline Psathyromyia bigeniculata & 1 & 1 & 0 & 0 & 0 & 0 & 0 & 0 & 1 & 1 & $4(0.12)$ \\
\hline Sciopemyia sordellii & 1 & 0 & 0 & 2 & 0 & 2 & 0 & 1 & 0 & 0 & $6(0.18)$ \\
\hline Total (\%) & \multicolumn{2}{|l|}{$2.012(59.79)$} & \multicolumn{2}{|l|}{$226(6.72)$} & \multicolumn{4}{|c|}{$1.127(33.49)$} & & & $3.365(100)$ \\
\hline Diversity Index $(\mathrm{H})$ & \multicolumn{2}{|l|}{1.2823} & \multicolumn{2}{|l|}{1.8694} & \multicolumn{4}{|c|}{1.5572} & & & 1.8529 \\
\hline Evenness Index (J) & \multicolumn{2}{|l|}{0.4999} & \multicolumn{2}{|l|}{0.7288} & \multicolumn{4}{|c|}{0.5901} & & & 0.6842 \\
\hline
\end{tabular}

$\mathrm{A}=$ urban area; $\mathrm{T} 1$ = transitional area; $\mathrm{T} 2-\mathrm{T} 4$ = wild area 
the total number of phlebotomines collected, followed by $\mathrm{Lu}$. longipalpis $17.27 \%$, Ev. lenti $15.66 \%$, Ev. evandroi $11.23 \%$, Br. avellari $9.42 \%$ and $N y$. neivai and Ev. sallesi, both with $4.07 \%$.

When testing these seven most prevalent species using ANOVA, four (Ev. sallesi, Lu. longipalpis, $N y$. intermedia and $N y$. neivai) showed significant differences in abundance among study sites $(\mathrm{p}<0.05)$, with greater abundance in the urban area (Table 2).

Species richness of phlebotomines was approximately equal in all of the areas, with 14 species being collected in the wild area and 13 in both the urban and transitional areas. The transitional area had the highest diversity and evenness values, 1.869 and 0.728 , respectively, whereas the urban area had the lowest, 1.282 and 0.499 , respectively (Table 1).

The species $N y$. whitmani was encountered exclusively in the transitional area whereas $M i$. quinquefer and $P a$. bigeniculata were not collected in this area. Pintomyia pessoai was collected only in the transitional and wild areas.

In the urban area, Ny. intermedia was the most abundant species with SISA $=1$, followed by $L u$. longipalpis (SISA =0.50), Ny. neivai (0.40) and Ev. sallesi (0.38). In the transitional area, Ev. evandroi was the most abundant (0.75) followed by Br. avellari (0.67) and Ev. lenti (0.50). This latter species was the most abundant species in the wild area with SISA $=0.92$, followed by $E v$. evandroi (SISA =0.61). Nyssomyia intermedia, Lu. longipalpis and Ev. sallesi were well distributed in the transitional and wild areas with very close SISA values (Fig 3).

\section{Discussion}

The presence of 15 species of phlebotomines in the collections made in the district of Barra do Guaicuí

Table 2 Main species of phlebotomines collected in urban, transition, and wild areas of the district of Barra do Guaicui, Minas Gerais, Brasil, during March 2013 to February 2014

\begin{tabular}{|c|c|c|c|c|c|c|c|}
\hline \multirow[b]{3}{*}{ Species } & \multicolumn{6}{|c|}{ Study area } & \multirow[b]{3}{*}{ Tota } \\
\hline & \multicolumn{2}{|c|}{ Urban } & \multicolumn{2}{|c|}{ Transitional } & \multicolumn{2}{|c|}{ Wild } & \\
\hline & $\mathrm{N}$ & $\%$ & $\mathrm{~N}$ & $\%$ & $\mathrm{~N}$ & $\%$ & \\
\hline Brumptomyia avellari & 28 & 0.86 & 58 & 1.78 & 231 & 7.09 & 317 \\
\hline Evandromyia evandroi & 14 & 0.43 & 58 & 1.78 & 306 & 9.39 & 378 \\
\hline Evandromyia lenti & 51 & 1.57 & 42 & 1.29 & 434 & 13.32 & 527 \\
\hline Evandromyia sallesi & 79 & $2.42^{a}$ & 5 & $0.15^{b}$ & 59 & $1.81^{b}$ & 143 \\
\hline Lutzomyia longipalpis & 536 & $16.45^{a}$ & 21 & $0.64^{b}$ & 24 & $0.74^{b}$ & 581 \\
\hline Nyssomyia intermedia & 1128 & $34.62^{a}$ & 27 & $0.83^{b}$ & 20 & $0.61^{b}$ & 1175 \\
\hline Nyssomyia neivai & 128 & $3.93^{\mathrm{a}}$ & 5 & $0.15^{b}$ & 4 & $0.12^{b}$ & 137 \\
\hline
\end{tabular}

${ }^{\mathrm{a}, \mathrm{b}}$ Different letters indicate significant differences between the columns; $p<0.05$ matches previous findings for the northern region of the state of Minas Gerais [18, 19].

The phlebotomine fauna found in the district of Barra do Guaicui showed to be diverse and predominantly comprised of important vector species, such as $L u$. longipalpis and $N y$. intermedia that are involved in disseminating the etiologic agents of VL and TL, respectively [20,21]. In addition to these species, Ev. lenti, Ev. sallesi, Ny. neivai and Ny. whitmani deserve attention because they have been found naturally infected and some may be involved in the wild and/or urban cycle of leishmaniases [21-24]. This faunistic composition is typical of modified environments near secondary forests, as seen in other areas of southeastern Brazil [25].

The species with the highest density was $N y$. intermedia, followed by Lu. longipalpis. These results are different from those observed in other studies conducted in northern Minas Gerais, where Lu. longipalpis was identified as the predominant species [19, 26, 27].

It is understood that there is a correlation between the density of $\mathrm{Lu}$. longipalpis and peridomicile conditions and this species is frequently associated with the presence of domestic animals [28, 29]. This behavioral characteristic was evident in the present study, since there were a greater number of individuals of this species in samples from peridomicile locations in urban area, with the presence of breeding animals.

The species Ny. intermedia was predominant in the urban area. This species is considered of great importance in the transmission of Leishmania braziliensis in southeastern Brazil [21, 30]. In Minas Gerais, Ny. intermedia is prevalent or quite abundant in endemic areas of TL. Gontijo et al., in a study conducted in a TL outbreak in Vale do Jequitinhonha, Minas Gerais, Brazil described the prevalence of $\mathrm{Ny}$. intermedia in the region and its preference for environments with a great degree of anthropic modification [31]. According to the high population density encountered in the district of Barra do Guaicuí, $N y$. intermedia may be participating in the transmission cycle of Leishmania species along with Lu. longipalpis.

When comparing the number of specimens in each studied environment greater capture success is evident in the urban environment. This capture success can be explained by the presence of domestic animals near the places where the traps were exposed. However, with regard to diversity, the opposite was observed, with the transitional area showing the greatest diversity, followed by the wild environment and lastly the urban area. The same trend was observed for the evenness index, which remained high in places with the greatest diversity of species, but low in the urban area, where $N y$. intermedia showed absolute dominance.

The fact that the urban area possesses some rural characteristics, such as livestock and subsistence crops, 


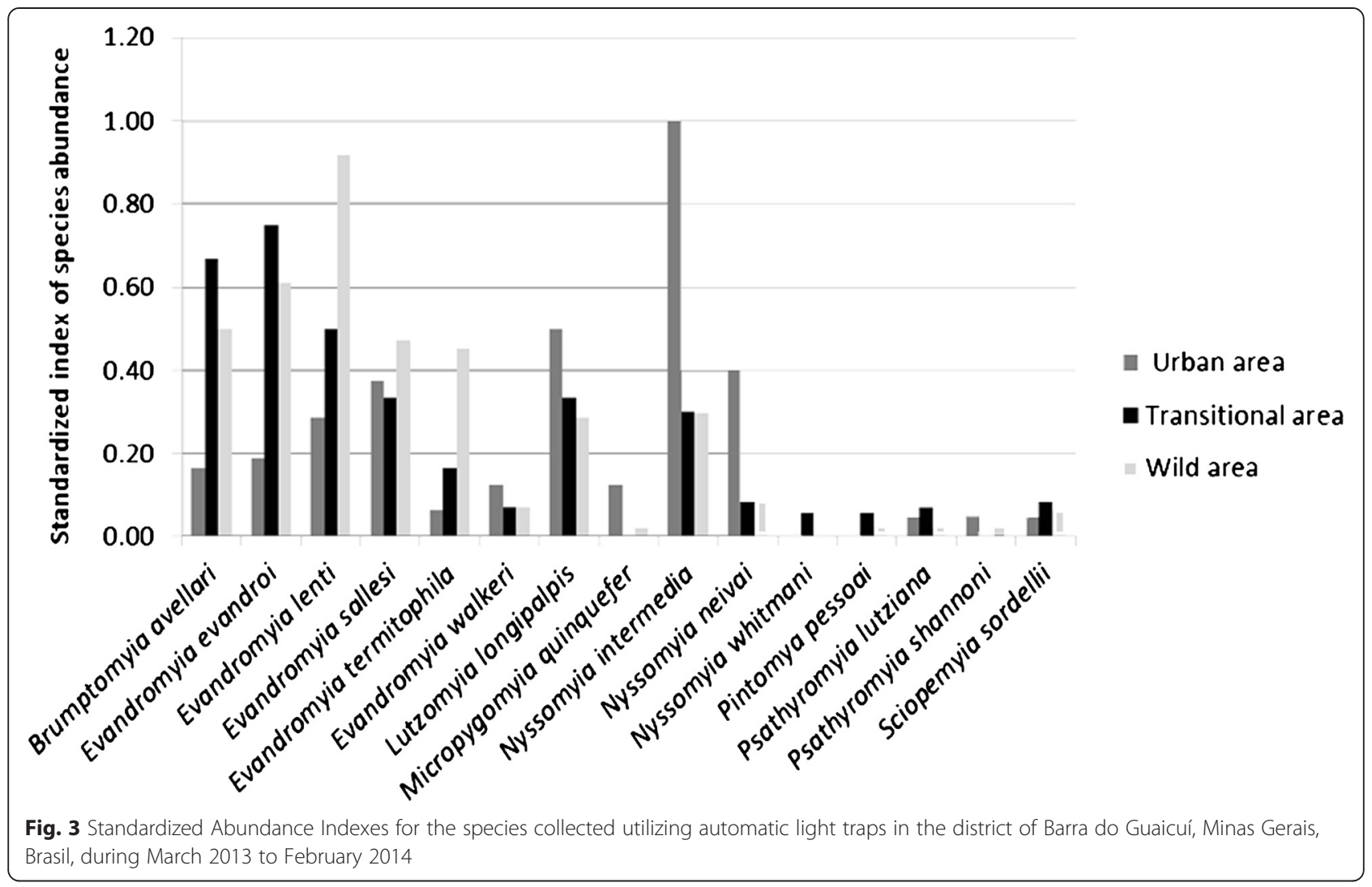

probably led to it having the largest number of insects collected. Some authors emphasize the importance of pigsties or chicken coops as risk factors because they serve as locations for the creation and maintenance of a high density of phlebotomines [32-35]. The greatest diversity $(\mathrm{H})$ in the transitional area can also be explained by the fact, that it is located between the forest and the urban environment.

The analysis of species abundance among the three areas showed different results in each of them, with absolute predominance of $N y$. intermedia in the urban area, Ev. evandroi in the transition area and Ev. lenti in the wild area. Galati et al., also reported $N y$. intermedia to have the highest SISA ranking in the Província Espeleológica do Vale do Ribeira, state of São Paulo, Brazil [36]. The populations of the species collected in the transitional and wild areas seem better adapted to forest environments, a fact also reported by other authors [37-39], unlike those species that predominate in urban areas that are better adapted to anthropic environments or forest edge [40-42]. Beyond these above mentioned species, it is important to highlight the presence of $\mathrm{Lu}$. longipalpis in urban areas, $\mathrm{Br}$. avellari and $E v$. lenti in the transition area and Ev. evandroi and $B r$. avellari in the wild area, all of these species with SISA above 0.50 .
Thus, whereas both areas have similar phlebotomine faunas, differing only in a few species, the situations with regard to the abundance of vectors of Leishmania spp. (Ny. intermedia, Ny. neivai, Ev. sallesi and Lu. longipalpis) are completely different. It was possible to confirm the pattern of adaptation of these species to peridomicile areas and the modified environment of the municipality of Várzea da Palma. The predominance of some species in urban environments is a relevant factor for the transmission of Leishmania species and has been mentioned in other faunal studies of phlebotomines [37, 43-45].

Although Ny. whitmani is represented by only one specimen in the district of Barra do Guaicuí, this finding requires special attention because of its implication as a potential vector of $L$. braziliensis in the northeast region of Brazil [20, 45].

Interesting to highlight the greater abundance of $N y$. intermedia compared to Lu. longipalpis in the urban area of Guaicuí bar district. This finding is different from that reported in studies in urban areas of Minas Gerais, where the predominance of $\mathrm{Lu}$. longipalpis is always registered [46-48]. Nyssomyia intermedia was found naturally infected by Leishmania infantum in Minas Gerais State and other regions of Brazil [22, 49, 50] and the highest population density in the urban area, which 
can be an indication that in this area this species may be playing a role in the transmission cycle of the L. infantum.

\section{Conclusion}

In a year of sand flies collection it was possible to demonstrate the distribution, richness and abundance of species in three different ecotypes. The distribution of the collected species showed distinct profiles between the environments, highlighting the potential risk of transmission of leishmaniasis in the urban environment where it was observed the highest population density and abundance of important vector species of Leishmania. Despite the different ecological characteristics between environments the richness of species was very similar between the areas. The results of this study contribute to understanding the gradual urbanization of the species of sand flies found in the state of Minas Gerais. Furthermore it demonstrates that the municipality of Várzea da Palma has several important characteristics for the expansion of visceral and cutaneous leishmaniasis.

\section{Competing interests}

The authors declare that they have no competing interests.

\section{Authors' contributions}

CCS, DFS, RGAVS, FDR, GBT, AT and JDAF participated in the collection of phlebotomines. CCS, DFS and JDAF were responsible for the identification of specimens and CCS, CMFG and JDAF participated in taxonomic discussions. CCS, CMFG, RGAVS, and JDAF drafted the manuscript. All the authors read and approved the final version of the manuscript.

\section{Acknowledgments}

The authors wish to thank the inhabitants of the municipality of Várzea da Palma for granting them access to their communities. We also wish to thank the Secretaria Municipal de Saúde de Várzea da Palma for their valuable assistance. JD Andrade Filho and CMF Gontijo are research fellows of CNPq.

\section{Author details \\ ${ }^{1}$ Leishmaniases Research Group, Phlebotomine Collection, National and International Reference Center for Phlebotomines, René Rachou Institute, Fiocruz, Av. Augusto de Lima 1715, 30190-002 Belo Horizonte, MG, Brasil. ${ }^{2}$ Universidade Federal de Minas Gerais (UFMG), Belo Horizonte, Brasil.}

Received: 27 May 2015 Accepted: 11 July 2015

Published online: 19 August 2015

\section{References}

1. Werneck GL. Forum: geographic spread and urbanization of visceral leishmaniasis in Brazil. Cad Saude Publica. 2008;24:2937-40.

2. Oliveira EF, Silva EA, Casaril AE, Fernandes CES, Paranhos Filho AC, Gamarra RM, et al. Behavioral aspects of Lutzomyia longipalpis (Diptera: Psychodidae) in urban área endemic for visceral leishmaniasis. J Med Entomol. 2013:50:277-84.

3. Harhay MO, Olliaro PL, Costa DL, Costa CHN. Urban parasitology: visceral leishmaniasis in Brazil. Trends Parasitol. 2011;27:403-9.

4. Sistema de Informação de Agravos de Notificação. Brasília: Ministério da Saúde. 2008. http://dtr2004.saude.gov.br/sinanweb/novo/.

5. Ministério da Saúde, Secretaria de Vigilância em Saúde. Departamento de Vigilância Epidemiológica: Manual de vigilância e controle da leishmaniose visceral. 2nd edition. Brasil: Ministério da Saúde; 2006.

6. Sousa RG, Santos JF, Rodrigues HG. Tales Alexandre Aversi-Ferreira: Casos de leishmaniose visceral registrados no município de Montes Claros, Estado de Minas Gerais. Acta Sci Health Sci. 2008;30:155-9.

7. Instituto Brasileiro de Geografia e Estatística: Cidades. 2014. http:// www.cidades.ibge.gov.br/xtras/perfil.php?lang=\&codmun=317080
8. Instituto Estadual de Florestas: Inventário Florestal de Minas Gerais. 2014. http://geosisemanet.meioambiente.mg.gov.br/inventarioFlorestal

9. Kottek M, Grieser J, Beck C, Rudolf B, Rubel F. World Map of the KöppenGeiger climate classification updated. Meteorol Z. 2006;15:259-63.

10. Kirwan GM, Barnett JM, Vasconcelos MF, Raposo MA, D'Angelo Neto S, Roesler I. Further comments on the avifauna of the middle São Francisco Valley, Minas Gerais, Brazil. Bull Br Ornithol Club. 2004;124:207-20.

11. Veloso HP, Rangel Filho ALR, Lima JCA. Classificação da vegetação brasileira, adaptada a um sistema universal. Rio de Janeiro: IBGE; 1991. 123.

12. Pugedo H, Barata RA, França-Silva JC, Silva JC, Dias ES. HP: um modelo aprimorado de armadilha luminosa de sucção para a captura de pequenos insetos. Rev Soc Bras Med Trop. 2005;38:70-2.

13. Grupo C, Bermudes H, Dedet JP, Falcão AL, Feliciangeli D, Ferro C, et al. Proposition of a standard description for Phlebotomine sand flies. Parasitologia. 1991;33:127-35.

14. Galati EAB: Morfologia e taxonomia. Classificação de Phlebotominae. In Flebotomíneos do Brasil. Edited by Rangel RF, Lainson R. Rio de Janeiro: Fiocruz; 2003: 23-206.

15. Marcondes CB. A proposal of generic and subgeneric abbreviations of phlebotomines sandflies (Diptera: Psychodidae: Phlebotominae) of the world. Entomol News. 2007;118:351-6.

16. Roberts DR, Hsi BP. An index of species abundance for use with mosquito surveillance data. Environ Entomol. 1979;8:1007-13.

17. Hayek LAC, Buzas MA. Surveying Natural Population. New York: Columbia University Press; 1997. p. 347-89.

18. Saraiva L, Carvalho GML, Sanguinette CC, Carvalho DAA, Falcão AL, Andrade Filho JD. Sandflies (Diptera: Psychodidae: Phlebotominae) collected on the banks of the Velhas River in the state of Minas Gerais, Brazil. Mem Inst Oswaldo Cruz. 2008;103:843-6.

19. Rêgo FD, Shimabukuro PHF, Quaresma PF, Coelho IR, Tonelli GB, Silva KMS, et al. Ecological aspects of the Phlebotominae fauna (Diptera: Psychodidae) in the Xakriabá Indigenous Reserve. Brazil Parasit Vectors. 2014;7:220.

20. Rangel EF, Lainson R: Ecologia das Leishmanioses. Flebotomíneos do Brasil. Edited by Rangel EF, Lainson R. Rio de Janeiro: Fiocruz; 2003: 291-309.

21. Andrade Filho JD, Galati EAB, Falcão AL. Nyssomyia intermedia (Lutz \& Neiva, 1912) and Nyssomyia neivai (Pinto, 1926) (Diptera: Psychodidae: Phlebotominae) geographical distribution and epidemiological importance. Mem Inst Oswaldo Cruz. 2007;102:481-7.

22. Saraiva L, Carvalho GML, Gontijo CMF, Quaresma PF, Lima AC. Natural infection of Lutzomyia neivai and Lutzomyia sallesi (Diptera: Psychodidae) by Leishmania infantum chagasi in Brazil. J Med Entomol. 2009;46:1159-63.

23. Carvalho GML, Andrade Filho JD, Falcão AL, Lima ACVM, Gontijo CMF. Naturally infected Lutzomyia sand flies in a Leishmania-endemic area of Brazil. Vector Borne Zoonotic Dis. 2008:8:407-14.

24. Margonari C, Soares RP, Andrade Filho JD, Xavier DC, Saraiva L, Fonseca AL, et al. Phlebotomine Sand Flies (Diptera: Psychodidae) and Leishmania Infection in Gafanhoto Park, Divinópolis, Brazil. J Med Entomol. 2010;47:1212-9.

25. Brazil RP, Passos WL, Fuzari AA, Falcão AL, Andrade Filho JD. The peridomiciliary sand fly fauna (Diptera: Psychodidae) in areas of cutaneous leishmaniasis in Além Paraiba, Minas Gerais, Brazil. J Vector Ecol. 2006;31:418-20.

26. Dias ES, França-Silva JC, Silva JC, Monteiro EM, Kenia MP, Gonçalves CM, et al. Flebotomíneos (Diptera: Psychodidae) de um foco de leishmaniose tegumentar no estado de Minas Gerais. Rev Soc Bras Med Trop. 2007:40:49-52

27. Monteiro EM, França-Silva JC, Costa RT, Costa DC, Barata RA, Paula EV, et al Leishmaniose visceral: Estudo de flebotomíneos e infecção canina em Montes Claros, Minas Gerais. Rev Soc Bras Med Trop. 2005;38:147-52.

28. Forattini OP. Novas observações sobre a biologia de flebótomos em condições naturais (Diptera: Psychodidae). Arq Hig Saude Publica. 1960;25:209-21.

29. Sherlock IA, Guitton N. Observações sobre Calazar em Jacobina, Bahia III - Alguns dados sobre o Phlebotomus longipalpis, o principal transmissor. Rev Bras Malariol Doen Trop. 1969;21:541-8.

30. Marcondes CB, Day JR, Ready PD. Introgression between Lutzomyia intermedia and both Lu neivai and Lu whitmani, and their roles as vectors of Leishmania braziliensis. Trans R Soc Trop Med Hyg. 1997;91:725-6.

31. Gontijo CMF, da Silva ES, de Fuccio MB, de Sousa MCA, Pacheco RS, Dias ES, et al. Epidemiological studies of an outbreak of cutaneous leishmaniasis in the Rio Jequitinhonha Valley, Minas Gerais, Brazil. Acta Trop. 2002;81:143-50. 
32. Galati EAB, Nunes VLB, Cristaldo G, Rocha HC. Aspectos do comportamento da fauna flebotomínea (Diptera: Psychodidae) em foco de leishmaniose visceral e tegumentar na Serra da Bodoquena e área adjacente, Estado de Mato Grosso do Sul, Brasil. Rev Patol Trop. 2003;32:235-61.

33. Oliveira AG, Galati EAB, Oliveira O, Oliveira GR, Espíndola IAC, Dorval MEC, et al. Abundance of Lutzomyia longipalpis (Diptera: Psychodidae: Phlebotominae) and urban transmission of visceral leishmaniasis in Campo Grande, state of Mato Grosso do Sul, Brazil. Mem Inst Oswaldo Cruz. 2006;101:869-74.

34. Alves GB, Oshiro ET, Leite MC, Melão AV, Ribeiro LM, Mateus NLF, et al. Phlebotomine sandflies fauna (Diptera: Psychodidae) at rural settlements in the municipality of Cáceres, state of Mato Grosso, Brazil. Rev Soc Bras Med Trop. 2012;45:437-43.

35. Ribeiro LM, Oshiro ET, Souza DA, Fernandes MF, Santos KM, Mateus NLF, et al. Biological aspects of immature stage of Nyssomyia whitmani (Antunes e Coutinho, 1939) (Diptera: Psychodidae: Phlebotominae) in laboratory conditions. Rev Bras Entomol. 2015;59:100-3.

36. Galati EAB, Marassá AM, Andrade RMG, Consales CA, Bueno EFM. Phlebotomines (Diptera: Psychodidae) in the speleological province of the Ribeira Valley: 2. Parque Estadual do Alto Ribeira (PETAR), São Paulo state, Brazil. Rev Bras Entomol. 2010;54:477-87.

37. Gomes AC, Galati EAB. Aspectos ecológicos da leishmaniose tegumentar americana. 7 - Capacidade vetorial flebotomínica em ambiente florestal primário do sistema da Serra do Mar, região do Vale do Ribeira, estado de São Paulo, Brasil. Rev Saúde Públ. 1989;23:136-42.

38. Marcondes CB, Santos-Neto LG, Lozovei AL. Ecology of phlebotomine sandflies (Diptera: Psychodidae) in Brazilian Atlantic Forest. Rev Soc Bras Med Trop. 2001;34:255-60.

39. Carvalho GML, Brazil RP, Ramos MCNF, Meira PCLS, Zenóbio APLA, Botelho HA, et al. Ecological Aspects of Phlebotomine Sandflies (Diptera: Psychodidae) from a Cave of the Speleological Province of Bambuí Brazil. PLOS ONE. 2013;8:77158.

40. Gomes AC, Rabello EX, Santos JLF, Galati EAB. Estudo experimental da freqüência de flebotomíneos a ecótopos artificiais com referência especial a Psychodopygus intermedius. Rev Saúde Públ. 1980;14:540-56.

41. Gomes AC, Rabello EX, Santos JLF, Galati EAB. Aspectos ecológicos da leishmaniose tegumentar americana. 3. Observações naturais sobre o ritmo diário da atividade de Psychodopygus intermedius em ambiente florestal e extraflorestal. Rev Saúde Públ. 1983;17:23-30.

42. Souza NA, Andrade-Coelho CA, Vilela ML, Rangel EF. The Phlebotominae sandfly (Diptera: Psychodidae) fauna of two Atlantic rain forest reserves in the state of Rio de Janeiro, Brazil. Mem Inst Oswaldo Cruz. 2001;96:319-24

43. Mayo RC, Casanova C, Mascarini LM, Pignatti MG, Rangel O, Galati EAB, et al. Flebotomíneos (Diptera, Psychodidae) de área de transmissão de leishmaniose tegumentar americana, no município de Itupeva, região sudeste do estado de São Paulo, Brasil. Rev Soc Bras Med Trop. 1998;31:339-45.

44. Andrade Filho JD, Valente MB, Andrade WA, Brazil RP, Falcão AL, Flebotomíneos do Estado de Tocantins, Brasil (Diptera: Psychodidae). Rev Soc Bras Med Trop. 2001;34:323-9.

45. Loiola CF, Silva DA, Galati EAB. Phlebotomine fauna (Diptera: Psychodidae) and species abundance in an endemic area of American cutaneous leishmaniasis in southeastern Minas Gerais, Brasil. Mem Inst Oswaldo Cruz. 2007;102:581-5.

46. Saraiva L, Andrade Filho JD, Falcão AL, Carvalho DAA, Souza CM, Freitas CR, et al. Phlebotominae fauna (Diptera: Psychodidae) in an urban district of Belo Horizonte, Brazil, endemic for visceral leishmaniasis: characterization of favoured locations as determined by spatial analysis. Acta Trop. 2011;117:137-45

47. Nascimento BWL, Saraiva L, Teixeira Neto RGA, Meira PCLS, Sanguinette CC, et al. Study of sand flies (Diptera: Psychodidade) in visceral and cutaneous leishmaniasis areas in central western of Minas Gerais state - Brazil. Acta Trop. 2013;125:262-8.

48. Carvalho GML, Gontijo CMF, Falcão AL, Andrade Filho JD. Study of phle-botomine sand flies (Diptera: Psychodidae) collected in a Leishmania-endemic area of the metropolitan region of Belo Horizonte Brazil. J Med Entomol. 2010;47(6):972-6.
49. Lainson R, Rangel EF. Lutzomyia longipalpis and the eco-epidemiology of American visceral leishmaniasis, with particular reference to Brazil: a review. Mem Inst Oswaldo Cruz. 2005;100:811-27.

50. Rêgo FD, Rugani JMN, Shimabukuro PHF, Tonelli GB, Quaresma PF, Gontijo CMF. Molecular detection of Leishmania in phlebotomine sand flies (Diptera: Psychodidae) from a cutaneous leishmaniasis focus at Xakriabá Indigenous Reserve Brazil. PLoS ONE. 2015;10:e0122038.

\section{Submit your next manuscript to BioMed Central and take full advantage of:}

- Convenient online submission

- Thorough peer review

- No space constraints or color figure charges

- Immediate publication on acceptance

- Inclusion in PubMed, CAS, Scopus and Google Scholar

- Research which is freely available for redistribution 